Michał Mochocki

Kazimierz Wielki University

\title{
Gamedec. UKW in IGDA Curriculum Framework
}

\section{History, Background and Vision}

The founder of Humanities 2.0, Prof. Mariusz Zawodniak, aimed to create an innovative BA programme that would combine the traditional liberal arts background (such as literature, philosophy, history and language studies) with new technologies, digital culture and practical ICT skills. Unlike other humanities-based degrees in Poland, this one was officially labelled as 'practical' instead of 'general-academic' (Polish degrees must choose one of the two). It was employability-oriented, dedicated to hands-on project work and collaboration with stakeholders outside of university. Prof. Zawodniak had initially planned three specialisations: E-Writing \& Computer Editing (for e-writers/editors), Online Journalism \& Social Media (for e-journalists and marketers), and Information \& Digitisation Society (for e-librarians). Responding to his call for curriculum contributions, I offered to create a fourth specialisation track: for game designers.

I had the necessary experience in higher-ed curriculum design, having been the head of the programme committee at the Institute of Modern Languages and Applied Linguistics for two years then, responsible for the redesign of BA and MA programmes in accordance with the National Qualification Framework. As highlighted by Extra Credits in their episode "On Game Schools" (2012, 5:51), it is also essential that at least some of the academics who run game degrees have real game industry experience. In the Humanities 2.0, the game staff comprised four teachers/researchers employed at the English Studies department. Dr. Paweł Schreiber had long been a video game critic, journalist and blogger, expert in interactive fiction, speaker at industry 
conferences and juror in game dev competitions (e.g. Indie Basement). Dr. Aleksandra Mochocka: a tabletop RPG writer and translator, also speaker and juror at game conventions. Mgr Mikołaj Sobociński: a practitioner and proponent of game-based learning. Dr. Michał Mochocki: a tabletop RPG designer, editor, writer and translator, larp designer, juror and speaker at game events, and game-based learning consultant with Nowa Era edu-publisher. Except for Schreiber, we had all experimented with edu-gamification. Except for Sobociński, we had also been members of Games Research Association of Poland, involved in academic game studies.

Summing up the legal, institutional, and organisational aspects:

2nd Gen Humanities was a 3-year (6-semester) full-time undergraduate (B.A.) programme, the total of 1800 contact hours, each semester comprising 15 teaching weeks.

It was offered to high-school graduates free-of-charge and without entrance exams, the selection process based on scores in high-school exit exam (matura).

Specialisation tracks would start already in Semester 2 and continue to 6, the total of exactly 720 contact hours in 12 modules.

In addition to the $720 \mathrm{~h}$, each specialisation had a 30-h introductory lecture in Semester 1, two special modules (Project + Collaboration with Stakeholders) in Semesters 2-4, and BA Seminar in 5-6.

The 'practical profile' of education focused on employability and skills, with the prospect of early start on the job market.

In line with the above, the game studies \& Design curriculum prioritised hands-on design labs run by instructors with relevant professional experience. Given the humanities-based nature of the degree and the specific expertise of the involved UKW staff, a substantial part of the curriculum focused on non-digital games: board \& card games, tabletop and live action role-playing, and urban location-based games. The digital section included interactive fiction and several (initially: 4) semesters of video games design labs with middleware tools (UDK, Unreal, Unity), which would be taught not by academics but by industry practitioners. There were also modules in educational games and gamification, their aim being to extend employability from commercial game development to serious games and also to non-game industries. Finally, there were game studies seminars to supplement the theoretical background provided by humanities and social studies modules in the general (i.e. non-specialisation) section of Humanities 2.0.

The semi-official name "Gamedec" was borrowed from a sci-fi novel series by Marcin Przybyłek, in which gamedecs are licensed investigators, experts and pro- 
blem-solvers in virtual MMO worlds. They combine technical skills with extensive knowledge of gameplay, game design, world-building, human (player) psychology and social behaviour.

\section{Literature Review: Academia and Industry}

Back in 2008, IGDA Framework said: "Over the last ten years, there has been a dramatic increase in the number and type of programs related to games" (p. 2). Seven years later, Frans Mäyrä (2015) in his keynote speech at CEEGS conference talks about the game academia as well-established, well-funded and thriving. Curricula and syllabi can be accessed online, and personal insights from both game students and teachers are proliferating on blogs and social media. Nevertheless, academic publications on game curriculum design are scarce, especially those relevant for Gamedec.UKW: rooted in the humanities and focused on employability-oriented skills across digital and non-digital platforms. Beside the IGDA Framework and the study of industry expectations vs game curricula by McGill (2009), primary sources consulted in the Gamedec curriculum design process (in 2012 and early 2013) were books intended to be used in college-level game education.

The classic Rules of Play by Salen \& Zimmerman (2003) helped define the scope and structure of the whole curriculum, its different chapters entering the reading lists of many modules across all three years. An Introduction to Games Studies by Mäyrä (2008) helped define the scope of digital game studies. The Art of Game Design: A Book of Lenses by Schell (2008) provided general guidance to practical game design and design thinking, applicable across all design labs. Also, together with Game Design Workshop by Fullerton (2008), it inspired the organisation of team-based game design projects and collaboration with industry partners. Challenges for Game Designers by Brathwaite \& Schreiber (2009) helped conceptualise the integration of non-digital and digital modules, and provided excellent exercises for students. A Theory of Fun for Game Design by Koster (2005) and The Gamification of Learning and Instruction by Kapp (2012) resonated well with our view of games as learning environments and of game design as parallel to instructional design, and reinforced our will to include edu-gamification and edu-games among Gamedec design labs. Together with Kapp (2012), The Multiplayer Classroom by Sheldon (2012) guided our efforts to gamify the learning process (see Mochocki, 2015). We also received personal advice from people involved in game degrees at Brunel University (UK): teacher Justin Parsler and graduate student Tomasz Kaczmarek.

Equally important as the academic sources was the voice of game industry professionals. The prior involvement of the English Studies / Gamedec.UKW staff with game 
design, gaming media and communities translated to a large network of connections to people employed in digital and non-digital game companies. This proved useful in obtaining direct feedback on the curriculum and general advice on what skills and qualifications are valued by the industry, and in discussing options for partnership and collaboration. At the preparation stage, this took the form of:

- Questionnaire about possible collaboration, internships and employment, taken by 13 game companies in May 2013 (results published on personal blog, Mochocki 2013),

- Attendance at game industry events (e.g. Poznan Game Arena, Game Developers Convention, Game Industry Trends, Pyrkon Festival, Game-based Learning conference) in order to: a) present Gamedec.UKW to the audience, b) listen to presentations on starting a career in game dev,

- Early arrangements with Vivid Games and CI Games about hiring their staff to teach Video Game Design at Gamedec.UKW,

- Informal personal communication with game dev professionals.

Given the number of conference talks and panels, invited guest lectures, and personal meetings, representing both digital and non-digital sectors in Poland (special thanks to Krzysztof Maliński, Maciej Miąsik, Rafał Bełka, Tomasz Kaczmarek, Ignacy Trzewiczek, Krzysztof Szafrański, Michał Stachyra) and abroad (special thanks: Justin Parsler, Sandy Petersen, Claus Raasted, Povl Heiberg Gad, Derrick Ferry, Yaraslau Kot, Gameforge team), it is not possible to recall precisely who-said-what. Other useful sources of industry opinion were Extra Credits episodes on game education (2012a, 2012b). Suffice it to say that all were strikingly similar, with many points overlapping, others complementary, never contradictory. They may be collectively summarised as follows:

Activities (what game students should do):

- Make games: the most important thing is actual practice of creating games

- Start small and finish early: it is better to have a portfolio of small completed projects than grand visions which are never finished

- Learn the tools: work hard on mastering the technical skills and tools

- Play games: have an extensive player's knowledge of games and game genres

- Get inspired: look for inspiration beyond games, to other media, science, life experience

- Network: connect with people who are already working in the industry

- Be visible: attend industry events, have an online portfolio, participate in the community 
Skills, personality, behaviour (what game students should be like):

- Be ready for criticism: do not get discouraged by online hate

- Kill your darlings: accept that a large part of your creative work will be abandoned

- Endure crunchtime: be able to stay productive and creative when working long hours

- Attention to details: pay it

- Teamwork: timeliness, team spirit, shared responsibility

- $\quad$ Respect partners: stay on good terms with co-workers and ex-partners

- Communicate: "single most core skill” (Extra Credits, 2012b, 0:48)

Based on both the industry and academic advice, it was obvious that design labs with team project work would constitute a significant, if not central, part of the curriculum. Such skills are valued even in programming-focused degrees in Computer Science departments (e.g. Bourdreaux, Etheridge \& Kumar, 2011, p. 26; Brown, Lee \& Alejandre, 2009, p. 240). Secondly, these skills should be integrated with game studies with a strong liberal arts background, as recommended e.g. by Extra Credits (2012a, 5:34), Elling (2013, p. 36), recently again by Extra Credits (2016, 4:27), and three fourths of respondents representing 73 higher-ed institutions granting video game degrees (HEVGA, 2015a, p. 4).

\section{Gamedec. UKW in IGDA Curriculum Framework}

As said above, in the first two iterations of the programme, the Gamedec specialisation block comprised 720 contact hours in 12 modules, plus three special modules conducted mainly in non-contact form: Project, Collaboration, and BA Seminar. Internal university regulations insisted that at least $50 \%$ of all contact hours be lectures. As much as possible, the lecture hours were concentrated in the general Humanities 2.0 modules so that labs and seminars could dominate in the specialisation blocks. The $50 \%$ requirement was later lifted for practical programmes, leading to a significantly higher number of practical classes in iterations 2015/16+. Table 1 (below) shows these changes for all versions of the programme.

\subsection{Gamedec. UKW Modules in Semesters}

Table 1 lists all modules in the Gamedec block, their assigned number of hours and class format (lecture, seminar, lab), as well as placement in semesters. 


\begin{tabular}{|c|c|c|}
\hline \multirow{2}{*}{$\begin{array}{l}\text { Semesters } \\
\text { (Levels) }\end{array}$} & \multicolumn{2}{|c|}{ GAMEDEC: game studies \& Design Modules } \\
\hline & $2013 / 14$ and $2014 / 15$ & $2015 / 16$ and $2016 / 17$ \\
\hline Level 1 & $\begin{array}{l}\text { Intro to game studies \& Design: } \\
30 \text { h lecture }\end{array}$ & 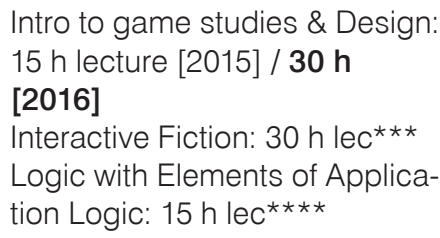 \\
\hline Level 2 & 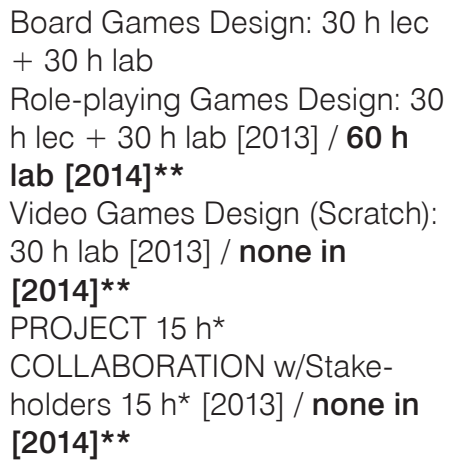 & $\begin{array}{l}\text { Board Games Design: } 30 \text { h lec } \\
+45 \text { h lab } \\
\text { Role-playing Games Design: } \\
30 \text { h lec }+30 \text { h RPG-Lab + } 45 \text { h } \\
\text { Larp-Lab } \\
\text { Law \& Economy of Game Indu- } \\
\text { stry: } 15 \text { h seminar } \\
\text { PROJECT } 15 \text { h* }\end{array}$ \\
\hline Level 3 & $\begin{array}{l}\text { Video Games Design: } 30 \mathrm{~h} \text { lab } \\
\text { Gamification of Education \& } \\
\text { Management: } 45 \mathrm{~h} \mathrm{lec}+30 \mathrm{~h} \\
\text { lab } \\
\text { PROJECT } 15 \mathrm{~h}^{*} \\
\text { COLLABORATION w/Stakehol- } \\
\text { ders } 15 \mathrm{~h}^{*}\end{array}$ & $\begin{array}{l}\text { Video Games Design: } 30 \mathrm{~h} \text { lab } \\
\text { Gamification of Education \& } \\
\text { Management: } 30 \mathrm{~h} \mathrm{lec}+45 \mathrm{~h} \\
\text { lab } \\
\text { Game Theory for Designers: } \\
30 \mathrm{~h} \text { seminar } \\
\text { Grant Writing: } 30 \mathrm{~h} \text { seminar } \\
\text { PROJECT } 15 \mathrm{~h} * \\
\text { COLLABORATION w/Stakehol- } \\
\text { ders } 15 \mathrm{~h}^{*}\end{array}$ \\
\hline Level 4 & $\begin{array}{l}\text { Video Games Design: } 30 \mathrm{~h} \text { lab } \\
\text { game studies: Ludology: } 30 \mathrm{~h} \\
\text { lec }+30 \text { h seminar } \\
\text { game studies: Narratology: } 30 \mathrm{~h} \\
\text { lec }+30 \mathrm{~h} \text { seminar } \\
\text { PROJECT 15h* } \\
\text { COLLABORATION w/Stakehol- } \\
\text { ders } 15 \mathrm{~h}^{\star}\end{array}$ & $\begin{array}{l}\text { Video Games Design: } 30 \text { h lab } \\
\text { ARG \& Urban Games: } 30 \text { h lec } \\
+45 \text { h lab } \\
\text { game studies: } 60 \text { h seminar } \\
\text { (with submodules) } \\
\text { PROJECT 15h* } \\
\text { COLLABORATION w/Stakehol- } \\
\text { ders } 15 \mathrm{~h}^{\star}\end{array}$ \\
\hline
\end{tabular}




\begin{tabular}{|c|c|c|}
\hline Level 5 & $\begin{array}{l}\text { Video Games Design: } 30 \text { h lab } \\
\text { Interactive Fiction: } 30 \text { h lec + } \\
30 \text { h lab } \\
\text { ARG \& Urban Games: } 30 \text { h lec } \\
+30 \text { h lab } \\
\text { BA SEMINAR: } 30 \text { h* }\end{array}$ & $\begin{array}{l}\text { Educational Games Design: } \\
30 \text { h lec }+45 \text { h lab } \\
\text { Games in Adaptations \& Trans- } \\
\text { media: } 30 \text { h seminar } \\
\text { game studies: } 60 \text { h seminar } \\
\text { (with submodules) } \\
\text { History of Digital Games: } \\
30 \text { h lec } \\
\text { BA SEMINAR: } 30 \mathrm{~h}^{\star}\end{array}$ \\
\hline Level 6 & $\begin{array}{l}\text { Educational Games Design: } \\
45 \mathrm{~h} \text { lec }+30 \mathrm{~h} \text { lab } \\
\text { History of Digital Games: } \\
30 \mathrm{~h} \text { lec } \\
\text { Gamer Communities in VR and } \\
\text { RL: } 30 \mathrm{~h} \text { lec } \\
\text { Games in Cultural Context: } \\
30 \text { h lec } \\
\text { BA SEMINAR: } 30 \mathrm{~h} *\end{array}$ & $\begin{array}{l}\text { BA SEMINAR: } 30 \mathrm{~h}^{\star} \\
\text { Industrial Placement: } 3 \text { months } \\
\text { (no contact hours at } \\
\text { university) }\end{array}$ \\
\hline
\end{tabular}

Table 1. Gamedec.UKW Modules in Semesters

\begin{abstract}
* Project, Collaboration with Stakeholders, and BA Seminar are not regular contact classes. The hour count is there only for the purpose of calculating salaries.

** The only modification in the second iteration of Gamedec curriculum was the deletion of Video Games Design on Level 2 in order to add the saved $30 \mathrm{~h}$ to Role-playing Games Design lab. The deletion of Collaboration with Stakeholders on Level 2 was a general decision for the whole Humanities 2.0.

*** In 2015, Interactive Fiction was moved to the general Humanities 2.0 block on Level 1. Technically, it was removed from the Gamedec block, leaving spare hours to be added to other Gamedec courses. In fact, gamedecs take this class anyway, together with all Level 1 students before they choose specialisations.
\end{abstract}

${ }_{* * * *}$ In 2015, Logic with Elements of Application Logic replaced Elements of Philosophy on Level 1. It does not belong to the Gamedec module block, but was added at the request of Gamedec staff as a welcome introduction to mathematical / algorithmic thinking (compare: Extra Credits, 2016, 5:15).

\title{
3.2 IGDA Core Topics and Gamedec.UKW Modules
}

The IGDA Framework outlines ten Core Topics relevant for game education. In Table 2, the topics are paired with the respective Gamedec.UKW and general Humanities 2.0 modules. Table 2 is based on the third (2015/16) iteration of the curriculum (almost identical with the 2016/2017). 


\begin{tabular}{|c|c|}
\hline IGDA Core Topic & Covered in Modules (2015/16): \\
\hline \multicolumn{2}{|l|}{ 3.1.1 Game Criticism } \\
\hline Game studies & $\begin{array}{l}\text { Lvl 1: Intro to game studies \& Design } \\
\text { Lvls 4-5: game studies } \\
\text { Lvl 5: History of Digital Games } \\
\text { Lvl 5: Games in Adaptations \& Transmedia } \\
\text { Lvls 2-5: lectures + labs for specific platforms (board, } \\
\text { larp, etc.) }\end{array}$ \\
\hline $\begin{array}{l}\text { Experience-centered } \\
\text { criticism }\end{array}$ & $\begin{array}{l}\text { Lvl 1: Intro to game studies \& Design } \\
\text { Lvls 4-5: game studies } \\
\text { Lvl 3: Gamification of Education \& Management } \\
\text { General H2.0 Block } \\
\text { Lvl 3: Sociology of the Internet } \\
\text { Lvl 4: Methodology of Social Research (in Cyberspace) }\end{array}$ \\
\hline $\begin{array}{l}\text { Consumer-oriented criti- } \\
\text { cism }\end{array}$ & $\begin{array}{l}\text { Lvl 2: Law \& Economy of Game Industry } \\
\text { Lvl 5: Games in Adaptations \& Transmedia } \\
\text { General H2.0 Block } \\
\text { Lvls 1-2: Language of Social Communication }\end{array}$ \\
\hline Genre analysis & $\begin{array}{l}\text { Lvl 1: Intro to game studies \& Design } \\
\text { Lvl 2: Board Games Design } \\
\text { Lvl 2: Role-playing Games Design } \\
\text { Lvl 4: ARG \& Urban Games } \\
\text { Lvls 4-5: game studies } \\
\text { Lvl 5: History of Digital Games }\end{array}$ \\
\hline Auteur studies & $\begin{array}{l}\text { Lvl 2: Law \& Economy of Game Industry } \\
\text { Lvl 5: Games in Adaptations \& Transmedia }\end{array}$ \\
\hline Analysis of Game Design & $\begin{array}{l}\text { Lvl 1: Interactive Fiction } \\
\text { Lvls 4-5: game studies } \\
\text { Lvl 5: History of Digital Games } \\
\text { Lvl 5: Games in Adaptations \& Transmedia } \\
\text { Lvls 2-5: lectures + labs for specific platforms (board, } \\
\text { larp, etc.) }\end{array}$ \\
\hline \multicolumn{2}{|l|}{$\begin{array}{l}\text { 3.1.2 Non-Game Media } \\
\text { Studies }\end{array}$} \\
\hline Media Research Methods & $\begin{array}{l}\text { Lvls 4-5: game studies } \\
\text { General H2.0 Block } \\
\text { Lvl 1: Popular Culture and the Internet } \\
\text { Lvl 1: 2nd Gen Humanities: Fields \& Disciplines } \\
\text { Lvls 2-5: Correspondence of Sciences and Arts } \\
\text { Lvl 4: Methodology of Social Research (in Cyberspace) }\end{array}$ \\
\hline
\end{tabular}




\begin{tabular}{|c|c|}
\hline Core Experiences & $\begin{array}{l}\text { Lvls 4-5: game studies } \\
\text { Lvls 2-5: lectures + labs for specific platforms (board, } \\
\text { larp, etc.) } \\
\text { General H2.0 Block } \\
\text { Lvl 1: Popular Culture and the Internet }\end{array}$ \\
\hline \multicolumn{2}{|l|}{ 3.2 Games and Society } \\
\hline Gaming Demographics & $\begin{array}{l}\text { Lvls 4-5: game studies } \\
\text { General H2.0 Block } \\
\text { Lvl 2: Society of Knowledge, Information and Digitisation } \\
\text { Lvl 3: Sociology of the Internet }\end{array}$ \\
\hline The "Cultures" of Gaming & $\begin{array}{l}\text { Lvls 4-5: game studies } \\
\text { Lvl 5: Games in Adaptations \& Transmedia } \\
\text { General H2.0 Block } \\
\text { Lvl 1: Popular Culture and the Internet } \\
\text { Lvl 3: Sociology of the Internet } \\
\text { Lvls 2-5: Correspondence of Sciences and Arts }\end{array}$ \\
\hline History & $\begin{array}{l}\text { Lvl 5: History of Digital Games } \\
\text { Lvls 2-5: lectures + labs for specific platforms (board, } \\
\text { larp, etc.) }\end{array}$ \\
\hline $\begin{array}{l}\text { Experience of Play/ Histori- } \\
\text { cal aspects }\end{array}$ & $\begin{array}{l}\text { Lvl 1: Intro to game studies \& Design } \\
\text { Lvls 4-5: game studies }\end{array}$ \\
\hline $\begin{array}{l}\text { Experience of Play/ Social } \\
\text { aspects }\end{array}$ & $\begin{array}{l}\text { Lvl 1: Intro to game studies \& Design } \\
\text { Lvl 2: Role-playing Games Design } \\
\text { Lvls 4-5: game studies } \\
\text { Lvl 5: Educational Games Design }\end{array}$ \\
\hline $\begin{array}{l}\text { Experience of Play/ Psycho- } \\
\text { logical aspects }\end{array}$ & $\begin{array}{l}\text { Lvl 1: Intro to game studies \& Design } \\
\text { Lvl 2: Role-playing Games Design } \\
\text { Lvl 3: Gamification of Education \& Management } \\
\text { Lvls 4-5: game studies } \\
\text { Lvl 5: Educational Games Design }\end{array}$ \\
\hline $\begin{array}{l}\text { Experience of Play/ Econo- } \\
\text { mic aspects }\end{array}$ & $\begin{array}{l}\text { Lvl 2: Law \& Economy of Game Industry } \\
\text { Lvl 3: Gamification of Education \& Management } \\
\text { Lvls 4-5: game studies } \\
\text { Lvl 5: Educational Games Design } \\
\text { Lvl 5: Games in Adaptations \& Transmedia }\end{array}$ \\
\hline $\begin{array}{l}\text { Experience of Play/ Human- } \\
\text {-machine interaction }\end{array}$ & $\begin{array}{l}\text { Lvl 3: Gamification of Education \& Management } \\
\text { Lvls 3-4: Video Games Design }\end{array}$ \\
\hline $\begin{array}{l}\text { The Construction of Games } \\
\text { / Historical aspects }\end{array}$ & Lvl 5: History of Digital Games \\
\hline $\begin{array}{l}\text { Anthropology of the Game } \\
\text { Industry }\end{array}$ & $\begin{array}{l}\text { Lvls 4-5: game studies } \\
\text { Lvl 5: Games in Adaptations \& Transmedia }\end{array}$ \\
\hline
\end{tabular}




\begin{tabular}{|c|c|}
\hline 3.3 Game Design & \\
\hline Atomic parts of games & $\begin{array}{l}\text { Lvl 2: Board Games Design } \\
\text { Lvl 3: Gamification of Education \& Management }\end{array}$ \\
\hline Play Mechanics & $\begin{array}{l}\text { Lvl 2: Board Games Design } \\
\text { Lvl 3: Gamification of Education \& Management } \\
\text { Lvls 4-5: game studies }\end{array}$ \\
\hline $\begin{array}{l}\text { Approaches to Game } \\
\text { Design }\end{array}$ & $\begin{array}{l}\text { Lvl 3: Game Theory for Designers } \\
\text { Lvls 4-5: game studies } \\
\text { Guest speakers }\end{array}$ \\
\hline $\begin{array}{l}\text { Boardgame and Roleplay- } \\
\text { ing Design }\end{array}$ & $\begin{array}{l}\text { Lvl 2: Board Games Design } \\
\text { Lvl 2: Role-playing Games Design } \\
\text { Lvls 4-5: game studies } \\
\text { Lvl 5: Educational Games Design }\end{array}$ \\
\hline Ideas & $\begin{array}{l}\text { Lvl 2: Board Games Design } \\
\text { Lvls 2-4: Project } \\
\text { Lvl 5: Educational Games Design } \\
\text { Lvls 5-6: BA Seminar (diploma project) }\end{array}$ \\
\hline Fun & $\begin{array}{l}\text { Lvl 1: Intro to game studies \& Design } \\
\text { Lvl 3: Gamification of Education \& Management }\end{array}$ \\
\hline Abstract Design Elements & $\begin{array}{l}\text { Lvl 3: Gamification of Education \& Management } \\
\text { Lvl 5: Educational Games Design }\end{array}$ \\
\hline $\begin{array}{l}\text { Psychological Design Con- } \\
\text { siderations }\end{array}$ & $\begin{array}{l}\text { Lvl 3: Gamification of Education \& Management } \\
\text { Lvls 4-5: game studies }\end{array}$ \\
\hline Interface Design & Lvls 3-4: Video Games Design \\
\hline Iterative Nature & $\begin{array}{l}\text { Lvls 2-4: Project } \\
\text { Lvls 5-6: BA Seminar (diploma project) }\end{array}$ \\
\hline Serious Game Design & $\begin{array}{l}\text { Lvl 1: Intro to game studies \& Design } \\
\text { Lvl 3: Gamification of Education \& Management } \\
\text { Lvl 5: Educational Games Design }\end{array}$ \\
\hline Practical Game Design & $\begin{array}{l}\text { Lvls 2-5: all design labs + lectures } \\
\text { Lvls 2-4: Project } \\
\text { Lvls 3-4: Collaboration with Stakeholders } \\
\text { Lvls 5-6: BA Seminar (diploma project) } \\
\text { Guest speakers }\end{array}$ \\
\hline 3.4 Game Programming & \\
\hline Game Engine Design & Lvls 3-4: Video Games Design \\
\hline $\begin{array}{l}\text { Design/Technology Syn- } \\
\text { thesis }\end{array}$ & Lvls 3-4: Video Games Design \\
\hline Graphics Programming & Lvls 3-4: Video Games Design \\
\hline
\end{tabular}




\begin{tabular}{|c|c|}
\hline 3.5 Visual Design & \\
\hline Basic Visual Design & $\begin{array}{l}\text { General H2.0 Block } \\
\text { Lvl 1: Basics of Computer Editing \& Design } \\
\text { Lvls 2-3: Visualisation of Knowledge \& Information }\end{array}$ \\
\hline $\begin{array}{l}\text { Visual narratives: painting, } \\
\text { comics, photography, film }\end{array}$ & $\begin{array}{l}\text { General H2.0 Block } \\
\text { Lvl 1: Basics of Computer Editing \& Design } \\
\text { Lvls 2-5: Correspondence of Sciences and Arts }\end{array}$ \\
\hline Motion Graphics & Lvls 3-4: Video Games Design \\
\hline Visual Asset Generation & Lvls 3-4: Video Games Design \\
\hline Architecture & Lvls 3-4: Video Games Design \\
\hline Working with 3D Hardware & Lvls 3-4: Video Games Design \\
\hline Information Visualisation & $\begin{array}{l}\text { General H2.0 Block } \\
\text { Lvls 2-3: Visualisation of Knowledge \& Information }\end{array}$ \\
\hline 3.6 Audio Design & None \\
\hline 3.7 Interactive Storytelling & \\
\hline $\begin{array}{l}\text { Story in Non-Interactive } \\
\text { Media }\end{array}$ & $\begin{array}{l}\text { Lvl 2: Role-playing Games Design } \\
\text { Lvls 4-5: game studies } \\
\text { Lvl 5: Games in Adaptations \& Transmedia }\end{array}$ \\
\hline $\begin{array}{l}\text { Narrative in Interactive } \\
\text { Media }\end{array}$ & $\begin{array}{l}\text { Lvl 1: Interactive Fiction } \\
\text { Lvl 2: Role-playing Games Design } \\
\text { Lvl 4: ARG \& Urban Games } \\
\text { Lvls 4-5: game studies } \\
\text { Lvl 5: Games in Adaptations \& Transmedia }\end{array}$ \\
\hline Writing for Other Media & $\begin{array}{l}\text { General H2.0 Block } \\
\text { Lvl 1: Popular Culture and the Internet }\end{array}$ \\
\hline 3.8 Game Production & $\begin{array}{l}\text { Lvls 2-4: Project } \\
\text { Lvls 3-4: Collaboration with Stakeholders } \\
\text { Lvls 5-6: BA Seminar (diploma projects) } \\
\text { Guest speakers }\end{array}$ \\
\hline 3.9 Business of Gaming & $\begin{array}{l}\text { Lvl 2: Law \& Economy of Game Industry } \\
\text { Lvls 3-4: Collaboration with Stakeholders } \\
\text { Lvl 5: History of Digital Games } \\
\text { Lvl 5: Games in Adaptations \& Transmedia } \\
\text { Guest speakers } \\
\text { General H2.0 Block } \\
\text { Lvl 1; 5: Internet Law }\end{array}$ \\
\hline
\end{tabular}

Table 2. IGDA Core Topics and Gamedec.UKW Modules 


\subsection{IGDA Institutional Considerations}

IGDA 2008 Framework lists the following nine qualities as "some of the components of a strong program" (p. 33). Gamedec.UKW meets 7,5 of these, the missing one being (4.) local IGDA chapter, and the missing half being (6.) labs and libraries.

\begin{tabular}{|c|c|}
\hline $\begin{array}{l}\text { IGDA Institutional Considerations } \\
\text { (p. 33) }\end{array}$ & How they apply to Gamedec.UKW \\
\hline $\begin{array}{l}\text { 1. Advisory Board (local professio- } \\
\text { nals if available) }\end{array}$ & $\begin{array}{l}\text { An informal network of consultants and } \\
\text { sponsors in local and national digital and } \\
\text { non-digital game companies: Huuuge } \\
\text { Games, Remivision, Insane Code, Rebel. } \\
\text { pl, Fabryka Kart Trefl. Never officially } \\
\text { formalised as Advisory Board, but a good } \\
\text { functional equivalent. }\end{array}$ \\
\hline $\begin{array}{l}\text { 2. Focus on portfolio development } \\
\text { (graduation requirement, professio- } \\
\text { nal/ academic judges) }\end{array}$ & $\begin{array}{l}\text { Mandatory game projects created in } \\
\text { all design labs, in all Project modules. } \\
\text { Evaluation by industry professionals } \\
\text { highly recommended in all projects, and } \\
\text { mandatory in BA diploma projects. }\end{array}$ \\
\hline $\begin{array}{l}\text { 3. Internship network with studios, } \\
\text { companies and community organi- } \\
\text { zations including non-profits. }\end{array}$ & $\begin{array}{l}\text { Established with local video game com- } \\
\text { panies: Huuuge Games, Vivid Games, } \\
\text { Remivision (all of which have already } \\
\text { employed gamedecs full-time), with local } \\
\text { board game store Centrum Gier Pegaz } \\
\text { and board game blog Przystanek Plan- } \\
\text { szówka. }\end{array}$ \\
\hline $\begin{array}{l}\text { 4. Relationship with local IGDA } \\
\text { chapter (student memberships) }\end{array}$ & No IGDA chapter exists in Poland. \\
\hline $\begin{array}{l}\text { 5. Faculty with industry experience } \\
\text { (especially for development-focused } \\
\text { programs) }\end{array}$ & $\begin{array}{l}\text { Beside the initial four UKW staff (see } \\
\text { above: History, Background and Vision), } \\
\text { Gamedec was joined by: } \\
\text { Krzysztof Chmielewski, larp designer and } \\
\text { educator } \\
\text { Piotr Milewski, larp designer, board \& card } \\
\text { game designer, game-based learning } \\
\text { expert } \\
\text { Piotr Pieńkowski, long-time editor-in-chief } \\
\text { of video game magazines, video and } \\
\text { board game designer } \\
\text { Łukasz Juszczak, editor at board game } \\
\text { blog "Przystanek Planszówka" } \\
\text { Vivid Games professionals teaching Video } \\
\text { Games Design (W. Dziuk, G. Brol, M. Dzi- } \\
\text { kowski, F. Kucharski) }\end{array}$ \\
\hline
\end{tabular}




\begin{tabular}{|l|l|}
\hline $\begin{array}{l}\text { 6. Labs and libraries (access to } \\
\text { hardware/software/games students } \\
\text { don't have) }\end{array}$ & $\begin{array}{l}\text { Available but underequipped, especially in } \\
\text { high-quality computer hardware. }\end{array}$ \\
\hline 7. Speaker program (bring current \\
professionals on campus) & $\begin{array}{l}\text { Guest speakers from local and national } \\
\text { digital and non-digital game industries on } \\
\text { campus: video game publishers, game/le- } \\
\text { vel/sound designers, media workers, mar- } \\
\text { keters, community managers, translators; } \\
\text { board/card game designers, publishers } \\
\text { and retailers; larp designers and event } \\
\text { organisers; tabletop RPG designers and } \\
\text { editors. Additionally, foreign guest lectures } \\
\text { via Skype: Sandy Petersen (USA), Claus } \\
\text { Raasted (Denmark), GameForge team } \\
\text { (Germany), Mads Haahr (Ireland). }\end{array}$ \\
\hline $\begin{array}{l}\text { 8. Mixed classes (courses involving } \\
\text { programmers and artists on same } \\
\text { project, team-based) }\end{array}$ & $\begin{array}{l}\text { Project module on semesters 2-4, with } \\
\text { three mixed team projects per semester. } \\
\text { Also, platform-specific design lab. }\end{array}$ \\
\hline $\begin{array}{l}\text { 9. Extracurricular projects (student- } \\
\text {-led mods, projects outside the } \\
\text { classroom) }\end{array}$ & $\begin{array}{l}\text { Project module is based entirely on stu- } \\
\text { dent-led projects developed beyond the } \\
\text { classroom. Collaboration with Stakehol- } \\
\text { ders is carried out with partners outside of } \\
\text { university. }\end{array}$ \\
\hline
\end{tabular}

\subsection{Special Modules, Employment Rate \& Retention Rate}

In the Project module (Levels 2-4), teams of gamedecs are required to create three small game projects per semester, using some professional project management tools (e.g. Gantt chart). In the Collaboration module (Levels 3-4), they collect experience in collaboration with stakeholders outside university; preferably, as long-term internships in game dev companies. In the BA Seminar, each gamedec develops their own game project supervised both by an academic supervisor and an informal 'supervisor' (consultant) from a relevant industry.

Emphasis on constant project work in contact with industry professionals contributes to a high employment rate: as of July 2016, as many as $39 \%$ of seniors and sophomores found full-time employment in video game dev before graduation (Gamedec. UKW 2016), with the number rising to 47\% in January 2017 (Gamedec.UKW 2017) - to be compared with 55,8\% within a year post graduation among graduates of Western (mostly US-based) degrees focused specifically on video games (HEVGA, 2015b, p. 3). On the other hand, the amount of hard work required systematically across semesters contributes to a high drop-out rate. The freshman-to-sophomore retention 
was only $55,5 \%$ in the first two cohorts, compared to $88 \%$ in video game degrees in the USA and $64,2 \%$ on average in US-based academic degrees (HEVGA, 2015a, p. 4).

This paper focuses on the composition of the curriculum in the view of the IGDA framework, thus the section on special modules, employability and retention is only briefly sketched. For a more detailed analysis of these aspects, see Mochocki 2016.

\section{Summary}

The curriculum of Gamedec.UKW specialisation within the Humanities 2.0 BA degree has a very strong coverage of the following IGDA core topics: 3.1.1 Game Criticism, 3.1.2 Non-Game Media Studies, 3.2. Games and Society, 3.3. Game Design, and a strong coverage of 3.7 Interactive Storytelling. It has a relatively weak coverage of 3.8 Game Production and 3.9 Business of Gaming, very weak for 3.4 Game Programming and 3.5 Visual Design, and zero for 3.6 Audio Design. Also, it meets 7.5 out of 9 Institutional Considerations which refer mainly to collaboration with the industry environment and the organisation of after-class student assignments. The two leading sections of the curriculum are: practical game design team projects and rich liberal arts background, in line with recommendations from both academia and game industry.

The curriculum has undergone a significant modification in its third year (2015/2016+), including the removal of regular classes from Semester 6, leaving only the BA Seminar and 3-month industrial placement. This provides students with a greater mobility: they do not need to be present at university, contacting their BA supervisor online. Also, they can merge the industrial traineeship with the seminar, building their BA project upon the design work they do for the company in the traineeship.

In my opinion, the $2015 / 16$ version of the programme is the best that we could achieve given the 'glass ceiling' of institutional, financial and organisational constraints as a specialisation of Humanities 2.0. Hence, no significant changes were introduced in the newest (fourth) iteration for 2016/2017. Further improvement of the curriculum would require the 'emancipation' of game studies \& Design as an independent degree with its own specialisations.

\section{APPENDIX}

Table 3 lists all modules taken by gamedecs in the 3 -year programme, including those in the general Humanities 2.0 section. 


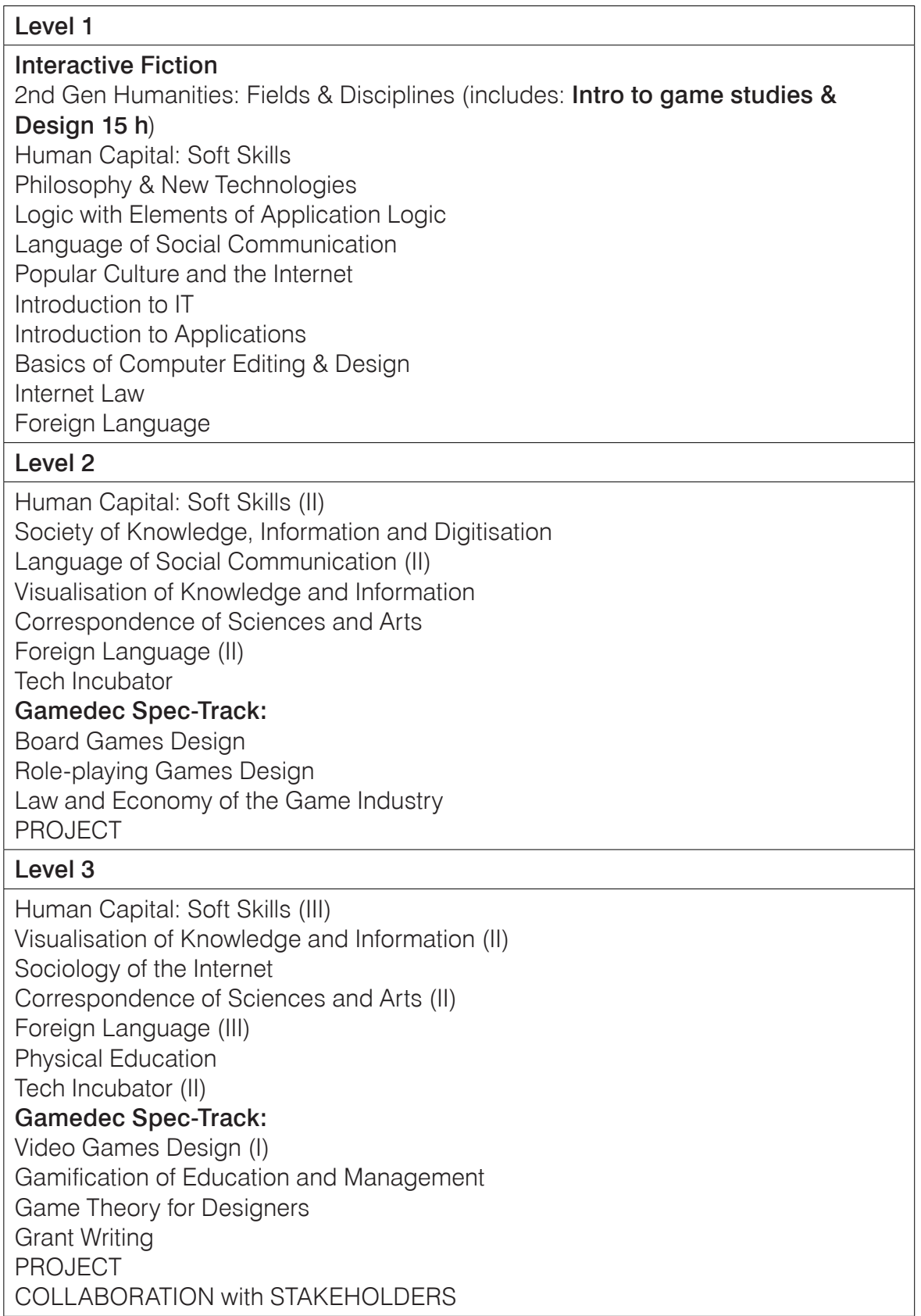




\begin{tabular}{|l|}
\hline Level 4 \\
\hline Ideas of Contemporary Humanities \\
Human Capital: Soft Skills (IV) \\
Methodology of Social Research (in Cyberspace) \\
Correspondence of Sciences and Arts (III) \\
Foreign Language (IV) \\
Gamedec Spec-Track: \\
ARG and Urban Games \\
Video Games Design (II) \\
game studies (I) \\
PROJECT \\
COLLABORATION with STAKEHOLDERS \\
\hline Level 5 \\
\hline Human Capital: Soft Skills (V) \\
Correspondence of Sciences and Arts (IV) \\
Internet Law (II) \\
free elective (lecture) \\
Gamedec Spec-Track: \\
Educational Games Design \\
Games in Adaptations and Transmedia \\
History of Digital Games \\
game studies (II) \\
B.A. SEMINAR \\
\hline Level 6 (no contact hours at university) \\
\hline Gamedec Spec-Track: \\
B.A. SEMINAR (II) \\
INDUSTRIAL PLACEMENT (3 months) \\
\hline
\end{tabular}

Table 3. Complete Gamedec.UKW 2015/16 Curriculum

References

Bourdreaux, H., Etheridge, J., \& Kumar, A. (2011). Evolving Interdisciplinary Collaborative Groups in a Game Development Course. The Journal of Game Design \& Development Education, (1), 25-37.

Brathwaite, B., \& Schreiber, I. (2009). Challenges for game designers. Boston, MA: Course Technology/Cengage Learning.

Brown, Q., Lee, F., \& Alejandre, S. (2009). Emphasizing soft skills and team development in an educational digital game design course (p. 240). In FDG '09 Proceedings of the 4th International Conference on Foundations of Digital Games. ACM Press. http://doi.org/10.1145/1536513.1536557 
Extra Credits. (2012a). On Game Schools. YouTube. Retrieved from https://www.youtube.com/watch? $\mathrm{v}=$ nmdGZk-fF98

Extra Credits. (2012b). So You Want To Be a Game Designer - Career Advice for Making Games. YouTube. Retrieved from https:/www.youtube.com/ watch? $\mathrm{v}=\mathrm{zQvWMdWhFCc}$

Extra Credits. (2016). Educating Game Designers - Too Much 'Game’ at Game Schools. YouTube. Retrieved from https://www.youtube.com/watch? $\mathrm{v}=\mathrm{kNscZCrke4k}$

Elling, K. (2013). 100 things every game student should know. Retrieved from https:// k0k0k0.files.wordpress.com/2013/05/100-things-every-game-student-shouldknow.pdf

Fullerton, T., Swain, C., \& Hoffman, S. (2008). Game design workshop: a playcentric approach to creating innovative games (2nd ed). Amsterdam; Boston: Elsevier Morgan Kaufmann.

Gamedec.UKW. (2016). 7-2016 Employability in Numbers. Retrieved from http://gamedec.ukw.edu.pl/7-2016-employability-in-numbers/

Gamedec.UKW. (2017). Employment. Retrieved from http://gamedec.ukw.edu.pl/employment/

GameForge. (2014, March). Guest lecture. Bydgoszcz.

Higher Education Video Game Alliance. (2015a). Our State of Play Higher Education Video Game Alliance Survey 2014-15. HEVGA. Retrieved from http://higheredgames.org/wp-content/themes/hevga_theme/assets/2015_HEVGA_Survey_ Results.pdf

Higher Education Video Game Alliance. (2015b). Priming the Pump 2015: Higher Education Video Game Alliance Survey of Program Graduates. HEVGA. Retrieved from http://higheredgames.org/wp-content/themes/hevga_theme/assets/ HEVGA_6-15-15des2.pdf

IGDA. (2008). IGDA Curriculum Framework. The Study of Games and Game Development. IGDA. Retrieved from http://www.igda.org/resource/ collection/0DBC56DC-B7CB-4140-BF3A-22A9E92EC63A/igda_curriculum_ framework_2008.pdf

Kaczmarek, T. (2013, November). Od Isaaca po mistrza gry, czyli jak nieznany rodzimy indyk podbił Polskę i wpłynął na studia gamedesignu w Anglii. Guest lecture, Bydgoszcz.

Kapp, K. M. (2012). The gamification of learning and instruction: game-based methods and strategies for training and education. San Francisco, CA: Pfeiffer.

Koster, R. (2005). A theory of fun for game design. Scottsdale, AZ: Paraglyph Press. 
Maliński, K. (2014, October). Jak zaczać jako programista $w$ branży gier. Presented at the Game Developer Convention, Poznań. Retrieved from https://www.youtube. com/watch?v=IKBOeMCEBp4

Mäyrä, F. (2008). An introduction to game studies: games in culture. London: SAGE.

Mäyrä, F. (2015, October). The Identity of game studies: The Widening Range of Research in Games and Play. Presented at the Central and Eastern European game studies. Distributed game studies, Kraków.

McGill, M. M. (2009). Defining the expectation gap: a comparison of industry needs and existing game development curriculum (p. 129). In FDG '09 Proceedings of the 4th International Conference on Foundations of Digital Games, ACM Press. http:// doi.org/10.1145/1536513.1536542

Mochocki, M. (2013, March 6). Gamedec New Info [blog post]. Retrieved from http:// mmochocki.blogspot.com/2013/06/gamedec-new-info.html

Mochocki, M. (2015). Gamedec. UKW: A case of edu-gamification for game designers. In Proceedings of 2015 International Conference on Interactive Mobile Communication Technologies and Learning (IMCL), Red Hook: Institute of Electrical and Electronics Engineers, pp. 323-326, http://dx.doi.org/10.1109/IMCTL.2015.7359612

Mochocki, M. (2016). Humanities-based degrees and game dev employability. In Computer Game Innovations, Łódź: Lodz University of Technology, pp. 80-105.

Parsler, J., Majkowski, T., Miąsik, M., Mochocki, M., \& Drews, M. (2012, October). Games and Education. Presented at the Game Developers Convention, Poznań. Retrieved from https://www.youtube.com/watch?v=2x37GVQZB3c

Petersen, S. (2014, May). Guest lecture. Bydgoszcz.

Raasted, C. (2014, June). Larp as a teaching tool. Guest lecture. Bydgoszcz.

Schell, J. (2008). The art of game design: a book of lenses. Amsterdam; Boston: Elsevier/ Morgan Kaufmann.

Sheldon, L. (2012). The multiplayer classroom: designing coursework as a game. Australia; Boston, Mass: Course Technology/Cengage Learning.

Salen, K., \& Zimmerman, E. (2003). Rules of play: game design fundamentals. Cambridge, Mass: MIT Press.

Summary

Launched in October 2013, GAMEDEC: game studies \& Design is a specialisation track within the 2nd Gen Humanities (aka Humanities 2.0) 3-year BA programme at Kazimierz Wielki University (UKW) in Bydgoszcz, Poland. The curriculum was 
created by UKW academic staff with game design experience, guided by the IGDA 2008 Framework and consulted with game dev professionals. It underwent slight modifications in 2014 and a significant transformation in 2015. This paper aims at a thorough analysis of the structure of the curriculum as seen through the lens of the IGDA Framework (2008), including the coverage of both Core Topics and Institutional Considerations. The analysis is conducted in the context of foreign (mostly U.S.-based) game degrees and supported with comments on its design, implementation and modifications.

Keywords: curriculum, game design, game studies, IGDA Curriculum Framework

dr Michał Mochocki - Assistant Professor in English Studies at Kazimierz Wielki University in Bydgoszcz and the creator of Gamedec: game studies \& Design specialisation path at Humanities 2.0. Co-founder of Games Research Association of Poland. His research interests include transmedia storytelling, non-digital role-playing games and game-based learning. 